\title{
Promises and Challenges of the International Criminal Court: view from a small State
}

\author{
By Dr. J. Enkhsaikhan (Mongolia)
}

\section{Introduction}

July 1, 2002, became a landmark in international community's quest for ending impunity for the most serious crimes and ensuring criminal prosecution for their perpetrators. On that day, an independent, permanent International Criminal Court (ICC) was established with clear jurisdiction to try perpetrators of crimes of genocide, crimes against humanity and war crimes. The ICC embodies the shared core values of human dignity and of peace and security. It is seen as a timely answer to the need to develop and strengthen the emerging international criminal justice system. The realistic character of ICC is reflected in the fact that it does not challenge the Westphalian system of international relations; it is based on the principle of complementarily and reflects current institutional and other structures of power.

\section{Main achievements of the ICC}

The ICC is a major achievement of the XX century, a century which has seen enormous progress in humankind's development as well as great tragedies unfold, bringing death and suffering to millions of human beings. It is rightly seen as the greatest advance in international law since the founding of the United Nations in 1945. Today it constitutes the missing link in international law that would enable the international community to bring justice to international criminals as well as serve as a warning for potential ones and their collaborators.

The culture of impunity is still prevalent in international relations and international law. At the same time the history of wars reveals the progressive increase in total number of victims, especially among the civilian population, which prompted speedy development of international humanitarian law. Thus, if in World War I 4\% of the total number of victims were civilians, it increased to almost $50 \%$ in World War II, $60 \%$ in the Korean war and $70 \%$ in the Vietnam war. The share of civilian casualties in the war in Afghanistan was also very high. At the same time it is also evident from the modern history that international crimes are increasingly committed in peace time and that according to UN about $80 \%$ of the victims of all armed conflicts are civilians. 
It could be said that until the creation of the ICC the measures taken by the international community in fighting international crimes have mostly been ex post facto and were limited in scope. Thus the creation of the International Criminal Tribunals for Yugoslavia (ICTY) and Rwanda (ICTR) by the UN Security Council were also ex post facto. The tribunals were set up after hundreds of thousands people had been massacred. Nevertheless the two ad hoc tribunals marked a step towards creation of the ICC. Since they were created by the Security Council under Chapter VII of the Charter they were legally binding on all States. On the other hand, they were more political organs subsidiary to the Council with jurisdiction limited in time and space, than independent legal bodies with universal jurisdiction.

The work on the Rome Statute enormously benefited from the experiences of the two ad hoc tribunals, contributed to further development of international humanitarian law and its extension to non-international armed conflicts. Their judgments, concerning genocide, command responsibility and other judgments may prove to be useful for the Court.

The Court embodies the ideals, ideas and norms developed so far by the previous ad hoc practices and the international criminal law development in general. ICC is not a supranational body, but an international agreement and, as such, depends to a great extent on cooperation with States and among them. It is based on the principle of complementarity and thus it does not replace national criminal systems, but rather complements them. Only in two cases will the Court get involved: a) when a national legal system is not able to investigate and prosecute persons alleged to have committed the crimes under its jurisdiction, for instance when such a system has collapsed; b) when a national legal system refuses or fails to investigate and prosecute such persons.

The material element of the criminal responsibility (actus reus), the intentional element (mens rea) and the conditions of admissibility of cases are all clearly spelt out in the Statute. Moreover, it has also codified the general principles of criminal law, including non bis in idem, nullum crimen sine lege, nulla poena sine lege, individual criminal responsibility, irrelevance of official capacity, presumption of innocence, etc. The Statute also reflected the high standards of criminal justice such as due process (judicial responsibility, nonretroactivity of punishment, etc), fair trial (impartial court established by the law, trying on the basis of legislation, being informed of the nature and cause of the charges, right to defend oneself), rights of the accused, rights of the third parties, compensation for victims and/or their families, etc. All these were 
elaborated and negotiated at great length and have been agreed upon by consensus.

\section{Expectations and weaknesses of the Court}

Historically, the ICC tries to fill the huge lacuna that existed so far in international criminal law: clear-cut definitions of crimes and effective mechanisms of enforcing the law and punishing criminals. On the other hand, the Rome Statute, being a product of long negotiations and delicate compromises, is not a perfect document and does not fully satisfy the interests of all States, including small States. The latter by their nature are interested in the rule of law: it is in their self-interest that the use of force is outlawed and that States and individuals are held responsible for their use. History demonstrates again and again that it is mainly the smaller States that usually fall victim of aggression or manipulated to be used in such aggression. In many cases they fall victim of tyrannical or repressive rule not without the influence of outside powers, where grave crimes are committed.

From the perspective of small States the weaknesses of the Court are:

1) The ICC Statute does not include the crime of aggression as one of the core crimes, even though for small States aggression has always been and still is the "threat of all threats." History, including that of the XX century, is full of wars of aggression, big and small, in which the smaller States usually have been the victims. In 1998 in Rome, where the draft Statute was finalized and adopted, the proponents of including the crime of aggression in the Statute did not insist on its inclusion, because they did not want to impede the speediest adoption of the Statute. They agreed that the question of adding aggression to the list of the core crimes in the Statute could be looked at again in seven years - that is in 2009 - once or if the definition of aggression is agreed upon by that time.

2) Despite the insistence of many States, the Statute does not cover the threat or use of nuclear, biological, and chemical weapons - that is, the use or threat of use of weapons of mass destruction.

3) The Statute does not include drug-related crimes or gross environmental crimes that might have long-lasting, devastating effects on human health or the environment. The difficulty of defining these crimes clearly should not be used as a pretext to exclude them from the Statute in the future. For 
Mongolia, the question of nuclear waste disposal by the two neighboring nuclear powers in the vicinity of its borders is of great concern.

4) Penalties envisaged in the Statute, even cumulative penalties, are not severe enough to deter many prospective perpetrators.

5) There are other weaknesses of substance and procedure in the Statute, with which many States are not satisfied, especially small States.

However, this does not mean that States should reject the Statute and the ICC. On the contrary. In Rome on July 17, 1998, 120 States overwhelmingly voted in favor of the Statute. It took only four years for the Statute to enter into force, showing how much support the Court enjoys in the international community. As of 25 June, 2003, 139 States have signed the Statute, and 90 have ratified it.

\section{Materialization of ideals of international criminal justice}

Although the idea of criminal prosecution of perpetrators of grave international crimes has always been on the minds of people, the actual process of creating an international criminal justice system started at the end of World War II, in 1945. Until then, international crimes, though deplored, were virtually not punishable. There were some attempts to bring to justice the perpetrators or organizers of international crimes, but they proved to be futile.

The first concrete steps to establish an international criminal court were made in 1945 and 1946, with the establishment of ad hoc international military tribunals in Nuremberg and Tokyo. Although a basis was laid then for the establishment of a permanent International Criminal Court, the cold war interrupted and impeded interstate cooperation in this field, like in virtually all other fields. The efforts of the U.N. International Law Commission to draft a Code of Offences against the Peace and Security of Mankind bore little fruit because of the cold war ideological and political confrontations and mutual suspicion. In the meantime, the international community witnessed over 250 conflicts that caused the deaths of 86 million civilians, while 170 million people were stripped of their rights, property, and dignity.

\section{Development of international criminal law}

The case for the permanent International Criminal Court was revived in the wake of the atrocities witnessed by the international community in early 1990s in former Yugoslavia and in Rwanda. In response to the genocide 
committed in former Yugoslavia, which claimed lives of at least 200,000 innocent civilians, the United Nations Security Council established in 1993 the International Criminal Tribunal for Yugoslavia with the purpose of to trying the perpetrators. In 1994, the International Criminal Tribunal for Rwanda was established to try the individuals responsible for genocide in Rwanda. During the civil war there, almost 800,000 people, mainly Tutsis, had been massacred.

With the establishment of these two ad hoc tribunals, the question of bringing perpetrators to justice was put on the agenda of the international community. Truth commissions, dismissal or suspension of officials implicated in such crimes, seizure of assets and property of convicted criminals, blocking of financial sources, compensation for victims and families, and other measures of accountability are now being used in many cases throughout the world.

In December of 2002, eight judges were sworn in to serve on the United Nations' special tribunal consisting of both international and national judges to try those accused of responsibility for war crimes in Sierra Leone's recent civil war. The tribunal is to try those responsible for the genocide that has claimed lives of tens of thousands of innocent civilians. In June 2003 the tribunal issued a warrant for the arrest of Charles Taylor, the current President of Liberia for his alleged support of rebel groups during the civil war in Sierra Leone. This unprecedented step underlines yet again the growing understanding of and need for accountability and ending impunity for the crimes committed. The Indonesian human rights court convicted the most notorious militia leader for crimes against humanity committed during the 1999 massacre in East Timore after its people voted for independence. There are talks of trying the leaders of the former Iraqi regime responsible for grave human rights violations and massacres.

In March of 2003, as a result of 5 years of hard negotiations, agreement has been reached between the United Nations and the Government of Cambodia to establish an ad hoc tribunal to investigate the genocide of 1.7 million Cambodians in the 1970s, when the Khmers Rouges were in power. The tribunal is to be composed of Cambodian and foreign judges. Although these and other similar measures are welcomed, however belatedly, they are all ad hoc measures and are limited in time and space.

At the national level, many States, including those that are not parties to ICC Statue are adopting legislation, such as war crimes laws, that are in line with the Statute. These measures are useful in making impunity and individual responsibility important principles of international criminal law. In 1993 Belgium has adopted an unusual war crimes law based on the principle of "universal jurisdiction" that allowed Belgian courts to consider cases of genocide 
and other atrocities committed in other countries. Thus it allowed plaintiffs to lodge war-crimes and crimes against humanity cases directly, with no decision by a prosecutor, and the cases were allowed to proceed against defendants who were not even present. In June 2003, bearing in mind the difficulties the legislation raised with respect to cases considered to have political aims, Belgium has revised the law to limit it to cases where Belgians and Belgian residents would be directly involved as victims or suspects. The Belgian example clearly demonstrates that the principle of "universal jurisdiction", though is gaining wide support, needs to be carefully defined so as not to allow it to be abused in international relations.

\section{Mongolia and the Court}

Mongolia has always been one of the ardent supporters of the creation of the ICC and of strengthening the international criminal justice system in general. In the past century, especially in its first part, Mongolia was victim of aggression and threats of it. Thus in 1919, 1921, and 1939, it became object of aggression or military incursions. In order to prevent invasion from one of its neighbors, Mongolia turned for help to the other neighbor, only to find itself in the "bear hug" of the latter.

Under Soviet pressure, Mongolia underwent Soviet-style social experimentation and manipulation. The ideological class struggle was imposed upon Mongolia, which divided the society into the working class and exploiters, into "reliables" and "unreliables." As a result of such a policy in the late 1930s, almost 10 percent of the entire population was exterminated or persecuted. The foreign and national schemers, organizers, and executioners of the policy of "class genocide" went unpunished.

In the early 1990s, both the Mongolian and Soviet or Russian governments formally admitted that crimes had been committed in late 1930s. However, since the crimes had been committed almost half a century ago and since the oppressive system has been overthrown, it was decided not to identify and pursue the executioners of purges and repressions. Today, the Mongolian government is compensating, though belatedly and almost symbolically, the families of the victims of those purges and repressions.

In our southern neighbor, the Great Proletarian Cultural Revolution of the mid-1960s to the 1970s, which is known as the "decade of chaos," saw hundreds of thousands of people, including Mongolian nationals, physically 
and mentally persecuted. No one was brought to justice for instigating or organizing the atrocities perpetrated during that period.

Mongolia is proud to be one of the founding members of the Court, one of its few Asian members ${ }^{1}$. It believes that the establishment of ICC is the first major practical step in institutionalizing an international criminal justice system. It believes that based on the principle of complementarity, the ICC can in due time increase accountability, nationally and internationally.

Now that the eighteen judges and the Prosecutor have been elected and sworn into office, the next important stage of development in the international criminal justice system will be the formation of the organs of the Court and taking first practical steps, in line with the principle of complementarity, to bring to justice individuals implicated in the commission of the crimes defined in the Statute and perpetrated after July 1, 2002. As of the creation of the Court in 2002, almost two hundred cases had been filed with it. Therefore it would be up to the Prosecutor and his team to make sure that only those cases that come under Court's jurisdiction would be taken up by it, and that justice would be rendered without undue delays.

\section{Misperceptions about the Court}

On the public relations side, the Court has to cope with two major misperceptions:

1) that it would be a supranational court, with powers superceding national laws and courts;

2) that the it would be a panacea for international crimes. Those are dangerous misperceptions. The ICC is not a supranational organ, and it will not automatically prevent international crimes. It could, if effective, render justice and deter crimes in many cases. It is generally agreed that much will depend on the Court's credibility and actions.

\section{Major challenge: United States' position}

Because of the above and similar misperceptions and insufficient information about the ICC, it seems that work needs to be undertaken to explain the nature and goals of the Court. That would enable many States to ratify the Statute speedily and become party to the Court. One of the challenges of the international community is to persuade U.S. not to take any measures that would in practice weaken ICC or the support of it. Work also needs to be undertaken

\footnotetext{
${ }^{1}$ Mongolia signed the Statute on 29 December 2001 and ratified it on 5 April, 2002
} 
by States parties to the Court to allay the unfounded fears and suspicions of those that see it as a possible threat to sovereignty of States and their actions.

Due to the role that U.S. plays in the world and to its enormous influence, its position viz-a-viz the Court is very important in making the activities of the Court effective and the Court itself truly universal in nature. Although the United States was in general supportive of the idea of strengthening international criminal law and participated actively in negotiating the Statute and other relevant documents of the ICC, it has some misgivings, which the overwhelming majority of the international community does not consider to be fully founded.

In a nutshell, the official U.S. position with respect to the ICC is as follows: the Court infringes on the sovereignty of States; it could be used in politically motivated trials; the prosecutor will be uncontrollable; the Court could threaten U.S. freedom of action, etc. The United States wanted exemptions from prosecution of both U.S. civilians and U.S. military personnel. Since demanding exceptions for U.S. citizens was not politically feasible, during negotiations of the draft Statute the United States even proposed that permanent members of the Security Council, or even all States, be allowed to protect their nationals from the ICC's reach. The main reasoning was that the United States played an exceptional role in international relations and, therefore, deserved exemptions from the rules that apply to other States.

Other States, naturally, did not accept this reasoning, believing that there should not be any exceptions to the rule of law and to equality before the law. Therefore, U.S. demand for ironclad guarantees that in any circumstances Americans be shielded from the ICC was not accepted in 1998 in Rome. The U.S. position is still not widely accepted today, though since some States in bilateral agreements with U.S. acquiesced to their demands. Many in Rome believed and still believe today that the international community had already made sufficient adjustments in the Statute to accommodate most of U.S. demands. Indeed, during negotiations since the mid-1990s on the text of the Statute, U.S. negotiators were very active and succeeded in having most of their proposals and concerns reflected in the negotiating text. As a result, there are adequate procedural safeguards in the Statute to protect States' prerogatives. The Court will act only in cases when the national courts are unable or unwilling to act. There is little doubt as to the ability of U.S. courts to render justice.

Many articles have appeared to try to explain Washington's official position. They reflect U.S. positions and apprehensions, especially those concerning the so-called uncontrolled prosecutor. Careful scrutiny of the Statute demonstrates that the prosecutor is not uncontrolled. The only circumstance 
when a State, even the United States, might be overruled is when the Pre-Trial Chamber overrules and authorizes the prosecutor to investigate or prosecute. Since the prosecutor and his deputies were elected by the Assembly of States Parties, they will be accountable to it as to the exercise of jurisdiction at various stages of future proceedings. All this leads us to believe that the problem lies not with the Statute but with the lack of political will on the part of the U.S..

\section{Article 16 and "blanket exemptions"}

Although most of U.S. concerns have been addressed in the Statute and the two subsidiary documents, the Clinton Administration signed the Rome Statute reluctantly on December 21, 2000. However, the Bush Administration not only "unsigned" the Statute in May 2002, which is an unprecedented step in modern history of international relations, but it has since working to discourage others from ratifying the Statute. In order to achieve its goal, in spring of 2002 U.S. threatened to veto the extension by the Security Council of UN peacekeeping missions in Bosnia and Herzegovina, unless U.S. concerns over immunity were addressed. Thus acting contrary to the spirit of Article 16 of the Statute ${ }^{2}$, the United States succeeded, through the Security Council of the United Nations and invoking Chapter VII (?!?) of the Charter, to weaken the ICC standing by demanding a blanket exemption of its personnel from all peacekeeping missions. Although the United States was not able to get unlimited blanket exemption, it was able, through Security Council resolution 1422 (2000), to obtain for itself and for other non-parties to the ICC Statute, that participate in U.N. established or authorized peacekeeping operations, annual, though potentially permanent, exemption from the purview of the Court. The resolution of the Security Council thus de facto allows States non-parties to multilateral agreements to subvert the fundamental principles of such agreements, in this case equality before the law. In practical terms it also amounts to misinterpretation of the Statute and its de facto amendment. The exemption applies not only to U.S. military personnel, but also to those of many other major powers and States that contribute their personnel to UN peacekeeping operations and are not parties to ICC. ${ }^{3}$ In June 2003 the U.S. was able to extend

${ }^{2}$ Article 16 of the Statute of ICC stipulates: "Deferral of investigation or prosecution. No investigation or prosecution may be commenced or proceeded with under this Statute for a period of 12 months after the Security Council, in a resolution, adopted under Chapter VII of the Charter of the United Nations, has requested the Court to that effect; that request may be renewed by the Council under the same conditions".

${ }^{3}$ As of June 2003 there are 14 UN peacekeeping operations in progress where almost 37.000 people are carrying out Security Council mandates. Over 18.000 of them represent States parties to the ICC and are thus already under the jurisdiction of the Court. Only $1.5 \%$ (or 558) are U.S. citizens; most of them are civilian police; there are only two troops under UN command. 
that exemption for another year through Security Council resolution 1487 $(2003)^{4}$, though, unlike the previous year, three member States (France, Germany and Syria) abstained and many States voiced their opposition to the extension of the exemption. Many believed that there was no basis to invoke Chapter VII of the Charter.

\section{Article 98 and "immunity agreements"}

In order to exempt further its soldiers and personnel from the ICC's complementarity jurisdiction, i.e. from even non - U.N. operations, and find a more durable solution to its concerns, the United States adopted in August 2002 the American Service members' Protection Act (ASPA), which authorizes U.S. President to use force, if necessary, to retrieve US nationals from detention by the Court and to withdraw military aid from the States that are unwilling to grant US nationals immunity from the Court through signing of the so-called Article 98 "impunity agreements".

Article 98 of the Statute ${ }^{5}$ was intended to address the possible conflict of the Statute with the existing international agreements, namely the Status of Forces Agreements (SOFAs) and the Status of Mission Agreements (SOMAs). The article was not intended to allow conclusion of new agreements ${ }^{6}$. Therefore signing of "impunity agreements" violates the obligations that States Parties to the Rome Statute have undertaken when acceding to the Court. As a result of its forceful campaigns, the U.S. has been able to conclude such agreements with 44 States, including with 18 States Parties to the Statute. The list shows that most of them are small and weak States. However, many States, including some NATO partners of the United States, are still resisting U.S. pressures.

${ }^{4}$ Security Council resolution 1487 (2003) stipulates, inter alia, that... "acting under Chapter VII of the Charter of the United Nations, ... the Council...1. Requests, consistent with the provisions of Article 16 of the Rome Statute, that the ICC, if a case arises involving current or former officials or personnel from a contributing State not Party to the Rome Statute over acts or omissions relating to a United Nations established or authorized operation, shall from for a 12 month period starting 1 July 2003 not commence or proceed with investigation or prosecution of any such case, unless the Security Council decides otherwise; 2. Expresses the intention to renew the request in paragraph 1 under the same conditions each 1 July for further 12-month periods for as long as may be necessary.

${ }^{5}$ Article 98 of ICC Statute reads as follows:

1. The Court may not proceed with a request for surrender or assistance which would require the requested State to act inconsistently with its obligations under international law with respect to the State or diplomatic immunity of a person or property of a third State, unless the Court can first obtain the cooperation of that third State for the waiver of the immunity.

2. The Court may not proceed with a request for surrender which would require the requested State to act inconsistently with its obligations under international agreements pursuant to which the consent of a sending State is required to surrender a person of that State to the Court, unless the Court can first obtain the cooperation of the sending State for the giving of consent for the surrender. 
Thus European States have been trying to adopt, with mixed results, a common approach or policy towards U.S. pressure by finding ways to address its concerns without undermining the ICC Statute.

It is to be hoped that as ICC begins its historic mission, the U.S. will be able to see that its apprehensions concerning the ICC were unfounded and that there are ample safeguards against its abuse for political or ideological considerations, and that U.S. would thus reconsider its opposition to the Court and would work with it.

\section{Mongolia's dilemma}

As of writing of this article, many States, including small States, are facing a dilemma: by their nature they are in favor of strengthening international law, including emerging international criminal justice system. Many of them are parties to the Rome Statute and are expected to abide by its provisions in accordance with the universally accepted principle of pacta sunt servanda. On the other hand, the world's most powerful State and the United Nations Security Council, which according to the UN Charter has the primary responsibility for the maintenance of international peace and security, and the decisions of which all member States have agreed to accept and carry out, ${ }^{7}$ are sending out a signal that would compel States either to act in contravention of the Rome Statute or Article 25 of the UN Charter. Many members of ICC have chosen to abide by the Rome Statute, while others have chosen to follow their immediate short term interests and are thus following the second option with the hope that in due time this dilemma could be resolved without harming the integrity of the Court.

Like all other States "caught between the rock and the hard place", Mongolia is also facing the same dilemma. Having been actively involved in the negotiation of the Rome Statute ${ }^{8}$ and having become one of the founding members of the Court, Mongolia has committed itself to uphold the principles and provisions of the Statute. Thus when signing and later ratifying the Statute, in line with the latter's Article 120, it did not make reservation. Explaining the

${ }^{6}$ Thus the drafting history reveals that Article 98 was not intended to include agreements such as the U.S. is proposing to others. Therefore such agreements, if concluded, cannot meet the requirements of good faith interpretation of the Statute.

7 Article 25 of the United Nations Charter stipulates: The Members of the United Nations agree to accept and carry out the decisions of the Security Council in accordance with the present Charter.

${ }^{8}$ Mongolia has consistently supported the inclusion of aggression in the list of crimes within the jurisdiction of the Court. It has also proposed that policies leading to widespread environmental degradation with grave and long-lasting effects on the health of the population, such as radiation by nuclear wastes or other similar acts, be included in the list of crimes. 
position of the Mongolian Government Mr. L. Erdenechuluun, Minister for Foreign Affairs of Mongolia declared on 15 September, 2002 at the General Assembly that Mongolia believed the Court could be instrumental in ending impunity and upholding justice, deterring future crimes and further strengthening international criminal law.

When the question concerning Article 16 and of the blanket exemptions were raised in 2002 at the United Nations Security Council, the representative of Mongolia made the following statement at the meeting of the Security Council explaining the position of the its Government:

"The ICC is expected to be a permanent, independent international court. It will not be bound by mandates that are specific in time and place. Its provisions are consistent with the Charter of the United Nations and is based on the principle of respect for sovereignty of States, which is manifested, inter alia, in the principle of complementarity of its jurisdiction. In other words, the Court would take action only when national legal systems are unable or unwilling to genuinely investigate or prosecute. Moreover, the Court has ratione temporis jurisdiction, i.e. it has jurisdiction only with respect to crimes committed after 1 July, 2002. Under Article 16 of the Statute, the Security Council can request, under Chapter VII of the Charter, the deferral of investigation or prosecution of a case for a period of 12 months. The request may be renewed by the Council under the same conditions.

.... Logically and legally, the two bodies, i.e. the Security Council and the ICC are expected to work together, and not one to the detriment of the other. No State should be placed in a situation when it is forced to breach its international obligations either under the Charter or the Statute. We believe that both the Security Council and the ICC should work together to strengthen international peace and security, the rule of law and international justice. Mongolia, one of the founding members of the ICC, is interested, like all others, in maintaining the integrity and effectiveness of the Court, since the very first days of its existence. We have faith in the integrity of the Court, since the Statute has adequate safeguards against its possible abuse. We believe that by its activities, the Court will be able to dispel any lingering doubts as to its impartiality and effectiveness. When considering the Court's jurisdiction, we should not forget that the main objective of the ICC is prosecution of individuals for the most heinous crimes that have been defined in Articles 5, 6, 7 and 8 of the Statute. In other words looking at a tree nearest to oneself, one should not forget the entire forest that is behind it." 
The representative of Mongolia ended his statement with expressing the hope that the Council would be able to find a solution that would respect the spirit and letter of the Statute and would not undermine the effective functioning of the Court and of the Council. After the deliberations, the Security Council adopted its resolution 1422 (2002) intended to prevent the Court from extending its jurisdiction over persons involved in operations established or authorized by the Security Council if they are nationals of States that are not parties to the ICC.

Like many other States, Mongolia was soon approached by the U.S. to conclude a bilateral agreement aimed at exempting Americans from the Court's jurisdiction. After some hesitation on 6 June, 2003 Mongolia agreed to the U.S. proposed draft without any changes or modifications.

The author believes that the U.S.-Mongolian agreement is in violation of Mongolia's commitments under the Rome Statute. Thus signing the agreement violates not only the spirit of Article 96 of the Statute and goes against good faith interpretation of the article, but also Article 86 and many other concrete articles. Moreover, if Mongolia was to agree to temporary exemption of U.S. personnel, then, bearing in mind the fact that United Nations Security Council had adopted resolutions 1422 (2002) and 1487 (2003), it should have:

Insisted on narrowing down the list of "persons" to be covered by the agreement and to limit them only to those stipulated in the Security Council resolutions (and not all U.S. nationals and all current and former U.S. military personnel);

Proposed narrowing down any reference to international tribunals for which the exemption might apply (and not agree to exempt the "persons" from surrender or transfer from "any international tribunal for any purpose, unless such tribunal has been established by the UN Security Council, as being asked by the U.S. from many States);

Insisted that the "persons" who are to be prosecuted for the crimes, mentioned in Article 5 of the Rome Statute, if extradited to U.S. be prosecuted by the appropriate courts;

Insisted that the question of application of the provisions of the agreement be based solely on the decisions of the Mongolian Government;

Insisted that the agreement make explicit reference to Security Council resolutions mentioned above;

Insisted that, like the Security Council resolutions mentioned above, the agreement be concluded for a period of one year or that its duration be linked to the decisions of the Security Council regarding Article 16 of the Rome Statute, 
its interpretation by the States Parties to the Statute or by the International Court of Justice in the form of advisory opinion;

made a declaration when signing and ratifying the agreement explaining the Government's position with respect to ICC Statute and the Security Council resolutions mentioned above.

Other challenges to ICC

Although the negative attitude of the United States towards the ICC is a major political and legal challenge, there are many other challenges that States are facing in order to fully implement the Rome Statute and thus make the Court an effective organ to fight impunity and deter crimes. One such challenge is to make the Court a truly universal body. At present, unlike the United Nations, it is far from being a universal body. Much needs to be done to convince States that may have second thoughts about the ICC, especially concerning its efficiency and effectiveness, that their active support could make a difference in strengthening international peace and security and in promoting peace with and through justice.

\section{Implementation of the Statute}

States that are members of the Court need to take measures to bring their legislation in conformity with the Rome Statute. Thus according to the Mongolian national legislation, once an international treaty is ratified by the State Great Hural, or Parliament, of Mongolia, it automatically becomes part of domestic legislation. Mongolia has recently revised its criminal and criminal procedural codes which reflect many of the provisions of the Statute. However, still, much needs to be done for smooth and full implementation of the provisions of the Statute. Thus the questions of extradition of Mongolian nationals and of the privileges and immunities of State officials need to be addressed. For example, Constitutional provisions on immunity do not explicitly make exceptions for the crimes of genocide, crimes against humanity, and war crimes. Mongolian criminal legislation needs to be further updated to reflect the accurate definitions of the crimes reflected in the Statue. As a State party, Mongolia needs to be able to provide all forms of cooperation to the Court and its organs, as stipulated in Part IX of the Statute. The legislation should also more fully reflect offences against the administration of justice. 


\section{Conclusion}

The Statute is not a perfect document and States know that. However, most of them also understand and accept that it is essential to advance the goal of ending impunity and preventing commission of grave international crimes, despite the difficulties and challenges that lie ahead. Many States, including Mongolia, have made their choice, and, despite some setbacks, are prepared to move ahead. Many more have yet to make their choice. The role of the United States in international relations is vital, and many States, including great powers such as Russia, China and India are waiting for the United States to take the lead in strengthening international criminal law and ending impunity. It is hoped that the United States will accept the historic challenge, join others, and become once again the primary force in strengthening peace and justice throughout the world. Acting together, States would be able to further strengthen the Court and make it a truly effective and efficient judicial organ to combat grave crimes and bring to justice their perpetrators. 